\title{
Evaluation of the Sudan School Certificate English Examinations
}

\author{
Dr. Ahmed Gumaa Siddiek \\ Al-Dawadami Community College- P.O.Box 18, Postal Code 11911 \\ King Saud University - KSA \\ E-mail: aahmedgumaa@yahoo.com
}

\begin{abstract}
Examinations - among other things - are tools of quality control by which we can measure the attainment of the national educational goals. High-quality examinations are means of evaluation that can help teachers modify their teaching techniques, as well as helping learners adjust their learning strategies. Examinations are also benchmarks that can assist decision makers to judge the success of their educational, social and political aims. This paper explores the features of the Sudan School Certificate English Examinations (SSC) from the perspective of content validly and comprehensiveness. The data was collected through a questionnaire and analytically processed by machine to come out with some findings that: the (SSC) English Examinations in their recent forms are incomprehensive and lack content validity. They are proficiency tests rather than scholastic standardized achievement examinations. Therefore, they have negative backwash in language education development in our country.
\end{abstract}

Keywords: Language testing, Achievement tests, Content validly, Comprehensiveness

\section{Introduction:}

In this paper, I intended to explore the characteristics of the English Language Examinations of the Sudan Secondary School Certificate (SSC). These examinations qualify candidates for university admission in our country. The paper aims at answering the following questions:

- Are the Sudan School Certificate English Examinations in their recent forms Standardized Scholastic Achievement Tests?

- Do these examinations have any content validity?

- Are these English Examinations comprehensive, e.g. covering most of the syllabus topics, and testing the language elements and skills that are embedded in textbooks of (SPINE SERIES)?

- Do these examinations cater for the students' geographical, cultural \& psychological environment?

- Are the raters (teachers) aware of the fact that, these tests are high-stake-examinations, on which serious decisions, on the student's future are made, and therefore, careful and reliable marking is always required?

- Do these Examinations in their recent forms have positive backwash on examiners and examinees as well?

- Do the Sudan School Certificate English Examinations in their recent forms attain the educational objectives as tailored by the Ministry of Education in the Sudan?

\subsection{Doubts \& Complaints}

There were and still are continuous complaints, among the community of the English language teachers and student's parents, about the poor results achieved by young Sudanese in English examinations. But the most serious complaints usually come from employers, who are unhappy with the performance of those graduates in their implementation of language skills in real life situations. It is a pity when you see a custom or passport officer, dealing with a foreigner in the airports or in the government offices, in poor English. The case is also tangible with the university newcomers as Al-Busairi (2008) notices that the new university entrants come with very poor English or with no English at all. Most of them could hardly write a brief paragraph in simple English; and one out of four is unable to construct even an elementary sentence. He believes that this is due to poor textbooks written in atmosphere of hasty frenzy wave of change concerned, with policies of Arabicazation and Re-origination of Knowledge. There are many factors behind the drop of English standard: such as poor teaching, lack of teaching aids accompanying the textbooks and the unattractiveness of the textbooks themselves as they do not satisfy the practical needs of the young learners. It is found that $95 \%$ of students, interviewed by Al Busairi (2008), expressed their dissatisfactions with the topics in the SPINE BOOKS because of their familiarity and the remaining 5\% said they learned little from them. There is also absence of fellow-up or poor assessment of these English language programmes. 


\section{Theoretical framework and Previous Studies}

Regular assessment of examinations is crucial, as examinations are tools of quality control that can help us determine the attainment of our national educational objectives. Examinations can help teachers modify their teaching techniques and adopt new teaching methods, if the old ones did not work. They also help the learners to adopt new learning strategies as well. Examinations at the end must have positive backwash on both the learner and the teacher, simultaneously.

The writer is concerned with this problem as a secondary school teacher for a long time and as a university professor as well; so he is in a position that can help him see the problem from different angles. The writer listens to many of his students doubtfully and distrustfully questioning the criteria used in evaluating their performance in their final examinations. Rumors go round the country that marks in the final exams, are processed and modified by using some mathematical tricks to raise the level of the pass mark in the school certificate. This sort of interference or (make up) process would definitely yield a negative backwash, e.g. the effect of test on teaching and learning. Backwash according to Hughes (1995), Priest (1996), and McNamara (2001) can be harmful or beneficial.

Many teachers are also unhappy with the structure of the recent (SSC) English examinations set-up. They say that the majority of the items of the exam are irrelevant, as they are usually extracted from old textbooks sources such as (THE NILE COURCE). These irrelevancies make students refrain from reading and referring to their textbooks. It also (frames) teachers to focus on teaching examination techniques rather than doing real teaching from the textbooks in their classrooms.

The (SSC) English examinations are expected to show the degree of students' achievements in the courses they read, but not their overall ability in language proficiency skills. Achievement tests, proficiency tests, are two major concepts in language testing, but to my dismay most of my secondary school collogues deny their familiarity with these technical terms. Testing courses are not included in graduate syllabus. They have just been included in some MA \& M.ED pogrammes recently in Khartoum and Nile Valley universities.

Achievement tests can help us measure the attainment of our pedagogical aims. This point can be supported by Menke (1998) who believes that if assessments are to be effective and useful for educators in instructional practice, they must be deeply entwined with the classroom teaching and learning. It can also be supported by Bronwyn (2002), that tests are aligned with standards and curricula, students will have an increased chance of demonstrating what they know and are able to do. Teachers of ELLs (English Language Learners) need to be involved in the decision-making process regarding which tests will be used.

Scholastic examinations-though very tedious and boring - are still a part of our duty to carry them out as teachers. So whether like it or not, teachers have to deal with them professionally and in the best possible way, because if tackled in the right way, examinations are a valuable aid both to the teacher and the learner. If we ask ourselves the right questions as Marshal (1984:97) puts it, we are likely to structure tests and examinations that will answer our questions and not just give a list of marks to satisfy the school authorities and parents.

Educational evaluation should be a qualitative, quantitative, objective and fair process. Structuring and running tests is a part of teachers' routine because, if tests are not the main element used to give students marks then how do teachers assess their success in a language classroom? Every day, as Rand (1997) puts it should be a "testing" situation in that teachers and students alike evaluate learning and are giving marks not according to how well the skills are used or how much language information is retained, but to how much effort is displayed by the student in learning the language.

Although we can not deny the importance of examinations as means of evaluation and measurement, it remains a neglected area by English language teachers as well as language researchers The researcher was keen to go through previous researches, but no survey of its kind was found in the evaluation of the English Language Examinations. So, to the best of my knowledge this study may be the first in this field.

\subsection{The Audience}

The results of this paper would be of great significance to the following people:

- The Teachers: It will help them modify their teaching techniques if the old ones did not work, they will have to shift to new ones.

- Test Designers: they can determine the success or the failure of their courses from these analyses.

Nunan and Lamb (1996) share the idea of what learners should be able to do as result of instructions. They believe that all language programs should take their form of departure from the goals and objectives that have 
been derived from an analysis of learner's needs. Vale: et al (1996:32) also distinguish goals which are generally stated from the teacher's perspective and provide direction for the teaching and learning, and objectives which spell out what learners will actually be able to do.

- Policy makers: These various high-stakes testing applications are enacted by policy makers with the intention of improving education. Ravitch (1997).

- Departments of educational evaluation: It is also hoped to provide these departments in the Ministry of Education and other higher educational institutes in concern, with some ideas that might help to improve the (SSC) Examinations in general, and the English language Examinations in particular.

This research can also be considered as an indirect assessment of the recent English Syllabus (SPINE 6) which is taught at the Secondary School.

\subsection{Language Tests as a tool for social and cultural purposes}

Using language tests as a tool for social and cultural purposes has long history. Poor performance on a test may have serious consequence, as McNamara: (2001:68) puts it that a single instance is enough to betray the identity which the test aims to detect. Proficiency tests have been used for purposes of exclusion.

McNamara told a story that prior to the Second World War, the Australian Government used a language test as a part of policy to exclude immigrants other than those coming from the British Isle. The applicant could have a dictation test in any language selected by the immigration officer. If the person passed the test in English, then any one of a range of other language could be used until the candidate failed. In one notorious case, a Hungarian Jewish refugee from Hitler persecution applied for immigrant status. He was a polyglot and passed the test in a number of languages before finally failing in Gaelic, thereby being refused entry and thus faced a tragic fate in Europe. A similar case took place in the Sudan, that (William Andrea) a famous Jazz singer and basketball player was shot dead because he failed a simple language test. The victim was unable to properly pronounce some Arabic words when a soldier in a check point was cross-examining passengers arriving into or leaving the capital city of Khartoum, after the failure of the coup-d'etat of June 1976. Bolla:(www:2005).

So, due to failure in pronouncing the words in proper Arabic the examinee (William Andrea) lost his life, because he was unable to identify himself as belonging to the ethnic group of the examiner who spoke Arabic as mother tongue. It needs mentioning that (William Andréa) failed the exam because he was originally not Arabic speaker. His father was Greek and his mother was a southerner, from one of the tribes of Southern Sudan. The test which (William) had to take was not a good one because it lacked the characteristics of a good test, among those characteristics, are the reliability, content validity in addition to comprehensiveness. (Andrea) took a very short high-stake examination in which an immediate decision was made by the soldier who told himself that, that 'guy' did not belong to Sudan; as it was said about the group of rebels who carried out the coup-d'état in June 1976. The blatancy of such a practice illustrates the possibility that language tests can form part of a politically and morally objectionable policy. McNamara: (2001:69)

Note: I have to mention that I had an email from one of the deceased cousin who told me another story that the deceased was not shot dead that way, but he was killed at home, defending his family against an army raid. I have also done some internet browsing by goggling (William Andrea) and found this story, that [this...] singer was liquidated by the Sudanese army during the invasion of the so-called Murtazaqa in Khartoum. For more details you can see Wada John (www:2003)

\subsection{High-Stake Examinations:}

This idea of (high-stake) examinations dominated the behaviour of the American family some decades ago. The term means the consequences associated with test results. American families, make important decisions, such as where to live, based on the scores from these tests, (www.ericcass:2003). This occurs because real estate agents use school test scores to rate neighborhood quality and this affects property values. Test scores have been shown to affect housing prices, resulting in a difference of about $\$ 9,000$ between homes in grade "A" or grade "B" neighborhoods. At the national and state levels, test scores are now commonly used to evaluate programs and allocate educational resources. Millions of dollars now hinge on the tested performance of students in educational and social programs.

The Sudan School Certificate Examination (SSC) in a way is similar to those high-stake examinations in the U.S.A and other European and Asian countries. They arouse national as well as international interest. Serious decisions are based on the results which students achieve. These results can shape and change the candidate's life and the life of his family. 


\section{Research Methodology}

To collect data, a questionnaire was carried out, (see table) through which I investigated the attitudes of English language teachers towards the comprehensiveness and content validity of the (SSC) English examinations. I also explored the elements of the (SSC) English examinations by going through the items of examination, taken by students during 2003-2008. The (NORMS) of (The Technical Guide of Secondary Examinations of 2003) were used as yardstick. According to these norms, the test constructor must put the general regulations of good examinations into consideration when writing the test.

\subsection{Data Analysis \& interpretations (see table)}

In this part, the paper is dealing directly with the analysis of the data collected through the questionnaire from a population of (77) subjects who represented the markers community in the (SSC) marking gathering of April 2004. The responses of the (77) subjects were tabulated and computed by applying the arithmetic mean (X) and the standard deviation (SD) for each statement to test the hypotheses round the mean, by using the (t) test at $(0.05)$ level of significance as illustrated in the table.

From the table (see appendices), all the subjects agreed that: the (SSC) English Examination is an achievement test, which helps us focus on the educational objectives of E.L.T. Generally, this is what is expected from achievements tests to do. Achievements tests firmly stick to examine the amount of information which the student came through in his/her course or unit. The subjects were also positive that the (SSC) English examinations could clarify the degree of objectives attained by both teachers and students. When the subjects were asked if achievement tests could help us discover inadequacies in curriculum content and organization, they all agreed to that, as this is exactly what achievement tests can tell us to do about the school programmes. The syllabus should be under continuous investigation to check its objectives which are expected to be subject to continuous revision and modification.

When the subjects were asked if these tests can help us do remedial work during the teaching of a certain course or unit, they all agreed to that. Teachers in their classes always need a tool with which they can continually measure their students' progress. Teacher-based Achievement can be of great help to do so. The subjects were also positive that these types of tests could help curriculum designers to detect the pitfalls of the syllabus in use. These tests can also enable teachers to discover the areas in which they may need help. The role of language supervisor is a major factor in the language education. The subjects believed that the supervisor of English is supposed to be an experienced person from whom the young teachers and learners can benefit. The researcher is sorry to say that there is a total absence of these experts in our schools.

The respondents also agreed that these tests could help us to determine the difficulty of a material that the learner might face. It is true, because a test is a mirror that reflects the performance of the students. All the respondents agreed that, those types of tests could have an effect on the teaching and the learning process. The results of examinations can always tell us about students, if their performance is good they would continue to keep this achievement, otherwise they will try to adjust their learning strategies to improve their performance in the next exam. This is what we call backwash of examinations. Examinations results can determine the effectiveness of teaching predominance in the classroom. If the students did well in exam then the teaching was definitely perfect, if there were poor results then we should check, among other things, the way students were taught. Examination results can also tell the syllabus designer about the success or failure of his/her programme. If the students' performance was good, then we could say that the course or the unit was a success, otherwise an immediate remedial work would be needed to make some change.

When the subjects were asked if the (SSC) English exam in its recent form tests students' ability to use English in real life situations; the majority of the respondents were in accordance with the concept of the achievement tests. It indicates that the majority of teachers were aware of the importance of standardized achievement tests which are supposed to have effect on language teaching and learning. Item number (9) which reads: The (SSC) Examinations have positive backwash (effect) on the students' performance in over-all language skills". This statement may be a subject for discussion as it is a controversial and disputable issue. What one can observe about the performance of students in the language in university doesn't support these assertions. Students find it hard to use the language in communication, speaking or writing. They also find great difficulty in using the language in real situations of interactions with others in the street, or in university or school classroom. (See Al-Busairi)

\subsection{The subjects were (not sure) about the following statements:}

3.2.1 Statement number 12: which reads: These tests can tell the student about his strengths and weakness to adjust his learning strategies in the future. The researcher agrees with the subjects in their uncertainty, since the 
students themselves-not their teachers would have better answered the question. Examinations are usually designed to secure this goal, examinations can tell the learner about the points oh his/her strength and can show $\mathrm{him} /$ her the places of weaknesses.

3.2.2 Statement 14: The (SSC) in its recent form tests the students' abilities rather than testing their achievements in specific task: The subjects may be uncertain because they do not realize the difference between an achievement test, that tests what the student actually studied in specific course or unit and the proficiency test, which tests the overall abilities of the students in the language without referring to one specific textbook or reference. The (SSC) in its recent form is a proficiency test because it does not stick to what is taught to students in their textbooks and lacks content validity.

3.2.3. Statement 15: Subjects are uncertain if the (SSC) exam in its recent form encourages students to refer and consult their textbooks (SPINE 6). The researcher had expected a positive response to this question. Most teachers know that their students refer to notes and books rather than the (SPINE 6). Students believe that the English Examinations usually borrow passages from outside their school Textbook (SPINE 6). The second evidence is that the market is full of books unprofessionally written by inexperienced teachers who seek profit but spoil the language. These books are badly written although they are published by official permission. These books spoil every educational effort to reform English teaching in the country. The third fact is that the teachers themselves do not teach the textbooks but focus on teaching techniques of how to respond to the examination items, to collect marks rather than doing real teaching or acquiring any kind of linguistic knowledge.

3.2.4. Statement 17: The (SSC) in its recent form attains the educational objectives of teaching English in the Sudan. It is a pity to say that most of the respondents are not sure about the Educational Objectives in general, and the specific objectives of teaching English language in the Sudan in specific. 'Educational Objectives' as described by Bloom and his colleagues in the (Taxonomy of Educational Objectives) is a concept unknown to most teachers. In a research carried out by Siddiek (2002), he found that his entire subjects did not hear with Bloom's Taxonomy, although they were professional teachers, with long experience in education. Specific objectives of teaching English in the Sudan are found in the TEACHER'S BOOK, but unfortunately very little number of teachers is aware of the existence of this manual, as it was found out by Ahmed (1995) in his research in SPINE Basic Level SERIS. Those teachers are not to blame because these MANUALS are not available for them, and they have to buy them in the market. It is the responsibility of the Ministry of Education to make these books accessible to the teaching force in the country.

3.2.5. Statement 18: The (SSC) English Examination in its recent form can help us predict the performance of students in higher institutes. According to his own experience as a university teacher, the researcher can assert that marks gained by the students in the (SSC) are not reliable measure to enable us predict the performance in their higher educational institutes. Teachers may be uncertain because they do not follow students up to universities and colleges. An investigation of this kind should be carried out by another researcher to see how students develop their knowledge and skills in English when they go to university.

3.2.6 Statements number 8,9,10,16,19 did not attain statistical difference between the mean and the test value which is (3), that means the subjects did not make a fixed opinions on those statements.

We can conclude from this questionnaire that the (SSC) English Examination is supposed to be a standardized achievement test, focusing mainly on the textbooks materials and topics, which are taught in the third class of the secondary school. Focusing on these textbooks will make the students grasp the vocabulary and the language structure embedded in the syllabus. The syllabus is supposed to be the minimum knowledge we want our students to attain in the school. But this is not the truth or even part of it as we have already seen in (Al Busairi) that $95 \%$ of the students showed no interest in their syllabus and $5 \%$ said that they did not learn any thing from those textbooks.

\section{Survey \& Critical Review of the (SSC) English Examinations (2003-2008)}

To my belief the major mistake that might have led to construct unsatisfactory examinations was due to the instructions and models that the test designers had to follow as prescribed in the (Technical Guide of the (SSC) Examinations of 2003). According to those criteria, things would have gone well, but when we examine the following models from the same manual, we will come to see differences and discrepancies. Let's now examine some samples.

\subsection{This example comes in the manual mentioned above.}

Read the following passage then answer the questions below: 
(Travelling can have its exciting though frustrating moments. A few ears ago I spent a week in France. The week was over and I was at the airport ready to leave when I discovered, to my dismay, that I had forgotten one of my suitcases at my hotel. Quickly I jumped into a Taxi and explained my situation to the driver. We sped off in the direction of my hotel. Suddenly, the taxi driver slowed down to talk with the driver of a truck moving along the road next to us. The truck contained live chickens. Without stopping the taxi, the taxi driver stuck his hand out of the window and took a live chicken, which he neatly stuck under the seat next to him. Meanwhile I was getting more and more anxious about my suitcase and making it to my plane on time. Time was not bothering to the taxi driver, though. Instead of heading for the hotel, he made a detour to drop the chicken off at his home! In the end, however, we managed to get the suitcase and then race back to the airport. Fortunately, I made it to my plane on time. What started out as a frustrating moment ended up being a hilarious memory and a great story?)

Comment:

NOW: What would you say about such nonsensicality?

- If you were the French Ambassador to the Sudan, would not you declare war against these Sudanese who are reflecting a negative image about the French people and the French culture in their students' textbooks?

- Is it the real picture that we want to see France and we want our young learners to see in their textbooks?

- Is it the picture of a well-to-do Sudanese who can afford to spend his vacation in France, but does not know how to manage his travelling programme and forget a suitcase in hotel?

- How many suitcases do we practically need to spend a week in France?

- Which was wiser and cheaper for him to take his plane and forget about the suitcase or to run such a risk to collect back the suitcase and miss his flight?

- How much petrol did the driver take to get to his home to drop the chicken to his (hungry wife and undernourished children)?

- Wouldn't be cheaper for that poor French driver to buy a chicken from the nearest supermarket instead of stealing one and make that long detour to drop it at home?

- $\quad$ Do the French people really suffer a famine?

- And does the writer suggest an urgent relief from our rich Sudanese people, who spend their holidays in a Francophone country instead of the old relationship with the Anglophones?

- $\quad$ And do the French steal the food when they feel hungry?

4.2 Such a model is un-educational because:

- It does not teach our students anything linguistically or culturally.

- It does not reinforce any positive pedagogical objectives or change any bad behaviour.

- It does not test any comprehensive abilities or skills.

- It reinforces wrong information about other people and other cultures.

- The candidates will say this is a lie.

- In all, it teaches absolute nonsensicalities to our young Sudanese learners.

4.3 Another example from page 18. It is a composition task about a "Holiday you spent in Benza the capital City of Nasa."

- Where is that Benza and where is that Nasa?

- Why wouldn't be Kassala or Al-Obied instead of those imaginative worlds?

- Why shouldn't we give the exam realistic and authenticated nature by giving real names of real objects like Sudan or England instead of Benza and Nasa?

4.4 Another model: This time is from the Administration General of Secondary school level, (2003). The candidates were required to write a composition on the following: (There is both temptation and fear to swim in the Nile: Write a composition of about 120 - 180 words, telling a story of how Hamid-a schoolboy - drowned while swimming. Then candidates were provided with guiding phrases as follows: Family and childhood: age, place in family, behaviour. School : punctuality, performance, relations, schoolmates, hopes

Swimming: idea, suggestion, fellows, time, place, drown, news, police informed, body found, hospital, surgery, Funeral: cemetery, grave, burial. 
Luckily, this was just a mock exam, as a part of training for the final exam.

I tried this exam with my students. When I began to DRAMATIZE the incident, most of the students felt sad for the story. Then I asked how many of them had run such an experience. Astonishingly, more than 50\% of my two $3^{\text {rd }}$ year classes had run such an experience. They missed at least one dear friend, colleague or close relatives. (Yosif...real name) began to shed tears. When I asked him about the reason of those tears I was unhappy to discover that the young boy did really run such an experience that he had missed his very own young brother who drowned in the NILE. So, how would you expect him to do in this composition exam? Definitely, such a topic would arouse a (hell) of sadness, which would affect the performance of the candidate in his examinations. Sadness and gloomy environment are two features of the (SSC) English Examinations.

4.5 Here is another example from March 2003 examination where the examinees were asked to write a composition. These guiding words were given to help them. (DEATH and INJURIES from motor cars accidents have become quite a problem on the major roads today. You have probably seen or heard about one such accident. Write a composition of about 120-180 words. You can use the following the following ideas or information if you like:

-Details of accident (date time place etc.....

-Why it happened: (bad weather, traffic, jam, overtaking, carelessness)

-Due to the accident: (some were injured, serious injuries, some died, others not harmed)

-If any off the above, What happened? (police, ambulance, hospitals,.......

Another gloomy example on the same exam the candidates were asked to read the following comprehension and answer the questions. The story was about ( TWO boats collided in bad weather......one carrying timber-the other was a ferry carrying people of course ... then you can imagine the gloomy story.

The second passage was a comprehension about Martin Luther King, the black American Civil Right Fighter who was shot dead 1968. Although it was a good story of a famous freedom and civil rights fighter, but the end of the story makes the candidates feel sad and angry against the Earl Ray who shot Martin Luther King dead and also they might feel angry with other good white men who on the other side supported King in his peaceful fight for justice and freedom. This plants seeds of racism and hatred.

4.6 Some more sad Grammatical models: look at these gloomy models:

- My brother (stand)..........there when the tree (fall).......yesterday. !!!

-You look tired. If I

-When I (come) ..........out of the school yesterday, I (find) .......that my bicycle ........(disappear).

-She (wait) ........for the bus in the bus station for half an hour everyday.!!! (neither she, nor the bus changes its bad habit !!!)

-The news (never be) ................good for the last few days. !!!!

•

(A) I wish I could stop smoking. !!!
Give
(B) I wish ...smoking. !!!
(bad habit)

4.7 Letter writing(April 2000).: Candidate were asked to write a letter with clear instructions that they should not mention any address. Because of the fear that they would give information about their personality which was supposed to remain uncovered for the examiners and the scorers. But aiming to achieve this goal, we would spoil the whole business of testing letter writing in English. Students all over the world are trained at school to differentiate between two forms of letters, the formal letter and the informal letter. So when we ask the students not to mention their address this will deprive us to teach the format of letter writing techniques in English. So, in order to emphasize the importance of the writing techniques of personal and business letters in English, the researcher suggests providing the candidates with full instructions. For example, we can give them the data as flows: (Your name is (Hassan). You live in KHARTOUM HAI EZEHOOR, BLC 34, P.O BOX 245, write a letter to your friend (Sami) who works for Nile Exporting Company. P.O.Box 11). So all candidates will write under the sender's name (Hassan) and under the addressee's name (Sami) to the same address mentioned. The candidates will then be told to stick firmly to the instructions.

4.8 The second question in paper two is the comprehension. Candidates were asked to read the passage then answer the questions, which were divided into short direct questions and multiple-choice questions. The problem appears with the multiple-choice questions where some distractors do not work properly. The comprehension 
passages were usually selected from outside the textbooks, although these textbooks (SPINE 4,5,6) consist of many interesting reading, material. This behaviour would result in negative response. Students would not focus in reading or referring to the passages in the SPINE because they believed that they would have a passage from an outside source. By doing so they would spoil all the efforts to study their syllabus and acquire the minimum knowledge to attain the objectives of the specific curriculum or syllabus. So reading (SPINE 6) is a waste of time as they thought. This is no doubt a very destructive behavior, when students loose confidence and interest in school textbooks. These textbooks cost money, time and efforts but for the gain of nothing.

Another problem appeared with the big space given for answering the questions. This space gave the candidate the chance to beat round the whole paragraph where the right answer was there.

4.9 In paper 2 there was a summary question of three short passages. The candidates were asked to read the passages and make a summary of about 20 words to sum up the main ideas in each piece. Here is an example. (A university student needs study skills. These are skills, which enable him to listen to a lecture or a talk on the radio and write down the main points which he can make use of later on. These skills also enable him to write a summary of a book or an article on a newspaper or a magazine. In this way he can make use of spoken and written material.) The summary passage was usually too short, easily be understood with very little effort. Such short passages do not encourage students to read longer passages later and hence, students would not take to the habit of reading loner passages and volumes in their free time. This will affect the factor of backwash in learning. Examinations need to have positive backwash in encouraging students to continue reading for information. A good test must enhance the desire of learning even if the student failed his examinations. The examination itself is a learning situation.

Another part of the exam is on grammar; too much attention is always given to grammar and always more grammar!! Other skills such as spelling, punctuation, capitalization etc. are neglected. The grammar testing is $40 \%$ of the total marks.

\section{The Rating Process of the (SSC) English Examinations:}

Markers usually gather in the capital city. They would have instructions given (orally) and then divided into groups under a group leader to begin their jobs.

Discrepancies: Examinations are usually collected from the regions and states in the country and packed to the Ministry of Education, where the Evaluation and Examinations Department is responsible of collecting and sorting the students' transcripts through the Examinations Control. This process of marking the examinations would run through many difficulties.

First: Centralization of marking papers in Khartoum cost a lot of time, money and human physical efforts. There is always danger of loosing papers during the transporting process of the exams from one region to another. The papers may be subject to loss or attack as it was said about the case of 2003 exanimations in Darfur. Sometimes examinations papers are subject to be spoilt by rain during transportation from regions to Khartoum and vise versa.

Second: The process of marking itself is very boring and teachers feel exhausted with very little rewarding. The work is also done under very poor conditions of accommodations. Stress can be noticed in the behavior of the markers inside the marking theatre. Many discrepancies arise due to differences in point of views between raters in evaluating the productive works of examinees especially in compositions and summaries. I was a part of a case when I noticed that an (X) student got 10 marks out of 10 in the comprehension, but the same candidate got only 6 marks out of 15 in his composition. Curiosity took me to investigate into the case by reading the composition; and astonishingly found that the candidate was doing very well in his/her composition. S/he was even very skillful in punctuation, capitalizing and spelling beside his/her neat work and arrangements of ideas. I insisted on re-checking the work and given the due marks. They did and the candidate was given 13 marks out of 15.

\section{Conclusion}

So referring to our questions at the beginning of our paper we can conclude that, the (Sudan School Certificate English Examination) in its recent form is not a standardized scholastic achievement test because it doesn't reflect the real performance of students in English, as standardized tests are supposed to attempt to provide authenticated information about the achievements of the individual learner of his/her course or unit. These examinations also lack content validity; test is said to have content validity if its content constitutes a representative sample of the language skills, structures, etc. with which it is meant to be concerned. The items in the (SSC) are unrepresentative, a thing that makes examinees refrain from referring to their textbooks and 
teachers focus on teaching examinations techniques only instead of doing real teaching of language skills. It is a big loss of money, time and efforts to gain nothing.

These examinations are incomprehensive because they do not cover the topics, elements and skills of language embedded in the syllabus textbooks of (SPINE SERIES). These tests also do not cater for the students geographical \& psychological environment as we could see from the sad models and irrelevant topics, such as asking students to write about issues of concern for the students in the urban areas, while the students in rural areas do not have any idea about them, such as writing a composition about AIDS, Internet, Industrial Development in Khartoum Region. The marking of the examinations is highly subjective, therefore, most of the judgments are unfair. These examinations in this form do not have any positive backwash as they do not encourage teachers or students to improve their teaching strategies. The Sudan School Certificate English Examinations in their recent format do not attain the educational objectives of teaching English language as tailored by the Ministry of Education in the Sudan, because they lack comprehensiveness and content validity. In a nutshell, they are proficiency tests rather than scholastic standardized examinations intended to test special language elements and skills and not to test the overall language abilities of these young learners.

\section{Recommendations \& Suggestions}

Language programmmes assessment is a neglected area in language education. To address these issue serious attempts should $b$ taken to run radical changes in the test format. Productive skills need to be examined in much more clearer way such as describing of events or transforming of statistical information by the interpretation of given data. Student can write from diagrams and table. More textual questions are needed to cover all the reading passages in the syllabus. More attention should be paid to the summary skills. Grammar can be examined objectively, in fact, a wide range of grammatical knowledge can be examined by MCQs. Language examinations should be in achievement test form and they must cover all items of the syllabus. Further, they should have content validity and must be highly representative of all the language elements and skills in the textbooks.

Further studies are needed to cover all aspects of language testing such as investigating the syllabus, analysis of item and content of the test. More researches are also needed to carry out investigations on the oral testing to reinforce the importance of using language in real situations.

\section{References}

Al-Busairi. Mohammed. (2008). Spine Series: A paper presented at Spine consultation workshop held by Open University of Sudan in Collaboration. with Cambridge University. Ministry of Higher Education and Scientific Research, Ministry of General Education and NCCER, Khartoum 10-11 June 2008.

A/Salam, Farouq M. Ahmed. (2002). Appraisal of Spine at the Basic School Level. Unpublished Ph.D. Omdurman Islamic University. Sudan.

Anderson, Scarvia B. (1975). Encyclopedia of Educational Objectives. Jossey-Bass Publisher, San Francisco. California.

Bolla, Abdullah. (2005).

line]).http://www.sudan-forall.org/sections/ihtiram/images/ihtiram-nov05-dr.bola.pdf. (Jan.2010).

Bronwyn, Carole. (2003). [On line] Available at http://www.cal.org.erriccl/Digest/subject/hhtp\#).

Hughes, Arthur. (1995). Testing for Language Teachers. Seventh Printing, University of Cambridge. Bell \& Bain, Ltd. Glasgow.

Lado, Robert. (1975). Language Testing. The Construction and Use of Foreign Language Tests. Wing Tasi Cheung Printing Company.

Marshall, Sylvia Temple. (1984). Educational Psychology for the Teacher in Africa. Edward Arnold. Ltd, 48 Bedford Square, London WC1b 3DQ. 97.

McNamara, Tim. ( 2001). Language Testing . Oxford University Press.

Menke, K. in Orlich, Donland.C, (et.al). (1998). Teaching Strategies. $5^{\text {th }}$ edition. Houghton Mifflin Company, Boston, New York. U.S.A.

Noah, Harold J. and Max A. Eckstein. (2003). [on line] (http://www.hku.hk.accec.html.

Nunan, D. and C. Lamb. (1996). [on line] (http://www.hku.hk.accec.html. (2003)

Nunnally, C. Jum:(1964). Educational Measurement and Evaluation. McCraw. Hill Book Company. 
Priest, J. (2003). (Unpublished PhD). Brunei Darussalam: http://www.surry.au.Eli.eli. (2002).

Rand, Wade. (1997) . Forum Magazine. August 1997.

Ravitch, Diane: (1997). National Tests: A Good Idea Gone Wrong. \{on line] http://ericcass/uncg.edu.virtaullib/newlihome.hotml. (2003).

Sax, Gilbert: (1980): Principles of Educational and Psychological Measurement and Evaluation. Second Edition, Wadsworth Publishing Company. Belmont, California.

Secondary School Certificate Technical Manual. (2003). Ministry of Education. Khartoum. Sudan.

Siddiek, Ahmed Gumaa. (2002) Analysis \& Evaluation of the Sudan School Certificate English Excavations; A Study based on Bloom's 'Taxonomy of Educational Objectives'. (Unpublished MA in TEFL, University of Juba, Sudan.

SPINE SERFIES 6. Textbooks. (1998). Printed \& distributed by The National Centre for Curriculum and Educational Research. Ministry of Education. Khartoum. Sudan.

Vale, D., A. Scarino, \& P. McKay: in (Maribel G. Valdez:1999). [on line] http://exchanges.state.govern./forum/vols/vol37/no1/index.html. (2003).

Vitek. In Orlich, Donland,C. et.al.(1998). Teaching Strategies. $5^{\text {th }}$ edition. Houghton Mifflin Company, Boston New York. U.S.A.

Wada, John. (2003). [on line] http://www.sudanforum.net/showthread.php?t=46527. (Jan. 2010)

Wiles, Kimball. (1963). The Changing Curriculum of the American High School. Prentice-Hall Inc. Englewood Cliffs, N.J. U.S.A.

Table 1. One-Sample Statistics Test is used.

I think......

\begin{tabular}{|c|c|c|c|c|c|c|c|c|}
\hline No & Statement & Mean & SD & $\mathrm{t}$ & Df & Sig. & Interp. & result \\
\hline 1 & $\begin{array}{l}\text { The (SSC) English examination is an } \\
\text { achievement test that helps students focus on } \\
\text { the educational objectives in textbooks. }\end{array}$ & 3.77 & 1.07 & 6.256 & 76 & .000 & Sign & agree \\
\hline 2 & $\begin{array}{l}\text { This English examination can clarify the } \\
\text { objectives attained by both teachers and } \\
\text { students. }\end{array}$ & 3.60 & 1.07 & 4.913 & 76 & .000 & Sign & agree \\
\hline 3 & $\begin{array}{l}\text { These tests can help us discover inadequacies } \\
\text { in curriculum content and make remedies. }\end{array}$ & 3.82 & 1.16 & 6.214 & 76 & .000 & Sign & agree \\
\hline 4 & $\begin{array}{l}\text { These tests can help us do remedial work } \\
\text { during the teaching of a specific course or unit }\end{array}$ & 3.94 & .85 & 9.674 & 76 & .000 & Sign & agree \\
\hline 5 & $\begin{array}{l}\text { These tests can determine the difficulty of } \\
\text { teaching materials. }\end{array}$ & 3.69 & 1.07 & 5.661 & 76 & .000 & Sign & agree \\
\hline 6 & $\begin{array}{l}\text { These tests can help curriculum designers } \\
\text { detect the pitfalls of the syllabus in use. }\end{array}$ & 3.71 & .98 & 6.364 & 76 & .000 & Sign & agree \\
\hline 7 & $\begin{array}{l}\text { These tests can enable teachers discover the } \\
\text { areas in which they may need help. }\end{array}$ & 3.73 & 1.14 & 5.584 & 76 & .000 & Sign & agree \\
\hline 8 & $\begin{array}{l}\text { These tests can tell us about the effectiveness } \\
\text { of the school administration. }\end{array}$ & 3.22 & 1.26 & 1.534 & 76 & .129 & $\begin{array}{l}\text { Non- } \\
\text { Sign }\end{array}$ & $\begin{array}{l}\text { There are no } \\
\text { significant } \\
\text { differences }\end{array}$ \\
\hline 9 & $\begin{array}{l}\text { The (SSC) Examinations have positive } \\
\text { backwash (effect) on the students' performance } \\
\text { in over-all language skills. }\end{array}$ & 3.00 & 1.15 & .000 & 76 & 1.00 & $\begin{array}{c}\text { Non-si } \\
\text { gn }\end{array}$ & $\begin{array}{l}\text { There are no } \\
\text { significant } \\
\text { differences }\end{array}$ \\
\hline 10 & $\begin{array}{l}\text { The (SSC) Examinations focus on testing the } \\
\text { material and the topics of (SPINE 6). }\end{array}$ & 3.08 & 1.34 & .512 & 76 & .610 & $\begin{array}{r}\text { Non-si } \\
\text { gn }\end{array}$ & $\begin{array}{l}\text { There's no } \\
\text { significant } \\
\text { difference }\end{array}$ \\
\hline
\end{tabular}




\begin{tabular}{|c|c|c|c|c|c|c|c|c|}
\hline 11 & $\begin{array}{l}\text { These types of tests can have an effect on } \\
\text { teaching and learning processes. }\end{array}$ & 3.66 & 1.12 & 5.192 & 76 & .000 & Sign & agree \\
\hline 12 & $\begin{array}{l}\text { These tests can tell the student about his } \\
\text { strength and weaknesses to adjust learning } \\
\text { strategies in the future. }\end{array}$ & 3.35 & 1.25 & 2.453 & 76 & 0.02 & Sign & Not sure \\
\hline 13 & $\begin{array}{l}\text { The (SSC) exam in its recent form tests } \\
\text { students' ability to use English in real life } \\
\text { situations. }\end{array}$ & 2.53 & 1.14 & -3.592 & 76 & .001 & Sign & Not sure \\
\hline 14 & $\begin{array}{l}\text { The (SSC) exam in its recent form tests } \\
\text { students' abilities rather than testing their } \\
\text { achievement in specific task. }\end{array}$ & 3.32 & 1.14 & 2.498 & 76 & .02 & Sign & Not sure \\
\hline 15 & $\begin{array}{l}\text { The (SSC) in recent form encourages students } \\
\text { to refer and consult their textbooks (SPINE 6). }\end{array}$ & 3.29 & 1.27 & 1.981 & 76 & .031 & Sign & Not sure \\
\hline 16 & $\begin{array}{l}\text { The (SSC) in its recent form attains the } \\
\text { educational objectives of teaching English in } \\
\text { the Sudan }\end{array}$ & 3.13 & 1.10 & 1.032 & 76 & .0 .31 & $\begin{array}{l}\text { Non- } \\
\text { Sign }\end{array}$ & Not sure \\
\hline 17 & $\begin{array}{l}\text { The arrangement of the test items is suitable in } \\
\text { both (SSC) Examinations papers. }\end{array}$ & 3.47 & 1.10 & 3.746 & 76 & .000 & Sign & Not sure \\
\hline 18 & $\begin{array}{l}\text { The (SSC) English examinations in recent form } \\
\text { can help us predict the performance of students } \\
\text { in higher institutes. }\end{array}$ & 3.43 & 1.22 & 3.386 & 76 & .000 & Sign & Not sure \\
\hline 19 & $\begin{array}{l}\text { These tests if set in objective multiple choices } \\
\text { will be reliable and valid tools to reflect the } \\
\text { truth about the students' performance in } \\
\text { language proficiency. }\end{array}$ & 2.88 & 1.20 & -853 & 76 & 0.40 & $\begin{array}{l}\text { Non- } \\
\text { sign }\end{array}$ & Not sure \\
\hline
\end{tabular}

The table shows the responses of (77) secondary school teachers. Khartoum (April, 2004) 